\title{
The Role of Work Life Quality towards Teacher's Professional Commitment
}

\author{
Nida Hasanati \\ University of Muhammadiyah Malang, Indonesia \\ nida3105@gmail.com
}

\begin{abstract}
Teachers are one of the major components in primary and secondary educations who have an important role to determine the future generations. To carry out these important tasks, teachers need a high level of commitment to the profession because it affects the teacher's related work outcomes. Factors that create professional commitment include quality of work life. This study aims to determine the role of quality of work life to the professional commitment of teachers. Subjects were teachers from junior school and high school. The research instrument used the scale of work life quality and the scale of professional commitment. Analysis technique used was the regression analysis. The results of the analysis showed: (1) the quality of work life significantly affects the affective commitment of the profession; (2) The quality of work life does not affect the continuance commitment to the profession; and (3) the quality of work life affects the normative commitment to the profession
\end{abstract}

Keywords: quality of work life, professional commitment, teacher

\section{INTRODUCTION}

The role of teachers in elementary to high education is very important, both to transfer knowledge and to form student's character. In order to prepare qualified graduates academically in both attitude and personality, it requires teachers who have high performances and are always ready to help colleagues and institutions to achieve the best results. Therefore, many researchers are interested in finding facts about the factors which improve work outcomes. One of the highlights of the research is about work commitments that have been shown to have a good effect on various outsourced jobs, such as organizational citizenship, turn over intention and, job performance.

Research about work commitment has been done frequently, mostly is related to organizational commitment. From previous research, organizational commitment affects various work outcomes. Organizational commitment has a positive impact on organizational citizenship behavior [19], organizational commitment determines a positive improvement in nursing work such as job satisfaction and compassion satisfaction [7].

Mayer \& Schoorman [16] argue that the effects of commitment are clear. Committed people will prefer to keep members of the organization work toward organizational goals and use more efforts in their work. Commitment has a variety of objects, therefore, explanation of other commitments often refers to organizational commitment or a derivation of organizational commitment. Professional commitment is a form of work commitment that is considered to affect performance and other work outcomes.

Research about professional commitment began to be done; from existing research commitment expressed has an influence on various employee's behavior. Previous research found that professional commitment influences lecturers' performance [5]. There is a positive and significant relationship among organizational commitment, professional commitment, and OCB. Nevertheless, results indicate a stronger professional commitment to correlate with OCB than with organizational commitment. While in more details, the commitment of the profession contributes 33 percent and organizational commitment by 9 percent [11]. [22], [11] found that professional commitment correlates with organizational commitment to project management and teachers. Other studies found a negative relationship between professional commitment and turnover intentions. Professional commitment predicts $30 \%$ of turnover intentions and $39.7 \%$ of the intention of leaving the profession [9]. The professional commitment also has an influence on adaptive performance [2]. In the accounting profession, the results of the commitment of the accounting profession and organizational commitment affect the auditor's job satisfaction. Professional commitment and commitment of the accountant organization affect audit quality, professional commitment, organizational commitment, job satisfaction from independent accountants, and the implementation of financial statements simultaneously [21]. Professional commitment owned by nurses directly affects job satisfaction and indirectly affects job stress through job satisfaction. This study explains that professional commitment plays a role as an antecedent of job satisfaction and stress on nurses [8]. From various previous sources, it can be concluded that professional commitment has influence on work performance, job 
satisfaction, organizational commitment, intentions turnover, and organizational citizenship behavior.

The professional commitment affects a variety of work behaviors, but the factors that make up the commitment of the profession have not been found. This is in contrast to organizational commitment that has been widely researched and has a sound theoretical framework. Nevertheless, some studies discussing it find that Advice network across divisions and Perceived organizational culture are correlated with professional commitment to nurses[24], achievement motivation influences affective and normative commitment to profession[5], competence has positive impact to affective commitment, commitment to continuity, and normative commitment to the profession[4]. Another study says that the value employees have in work has a positive effect on professional commitment[6]

Previous studies have shown that job satisfaction has a positive correlation with professional commitment [3][17], which means that employees who are satisfied with their work will be followed by increased professional commitment. The concept of job satisfaction has similarities with the definition of quality of work life, that is the evaluation of all things that have been obtained by employees in their work. The difference is the quality of work life is still in the scope of cognitive while satisfaction is already involved affective. Therefore, it is estimated that quality of work life will also affect the professional commitment.

There appeared to be no one commonly accepted definition for quality of work life; "employee's satisfaction with a variety of needs through resources, activities, and outcomes stemming from participation in the workplace"[14]. For the purposes of this study, based on Sirgy et al.'s definition[14], the quality of work life is defined as "not only employees' opinions, attitudes, and expectations about their job but also interpretation of all conditions and satisfaction of employees' needs by the employees as well as their perception of this satisfaction and conditions". [13] and [18], the key concepts captured in QWL include job security, better reward systems, higher pay, opportunity for growth, and participative groups among others.

Quality of work life that reflects how the organization can meet the needs of employees is assumed to have a positive impact on work behavior. Physiological and psychological senses of security will arise if the employee does not think about how to meet his needs. The quality of a good work life will cultivate a feeling of being happy with the profession so that employees can enjoy the tasks assigned. Employees who assess quality of work life are good, then they will be willing to continue to run the profession by reason of emotional closeness with the profession (Affective Commitment). To increase the willingness to accept responsibility of the tasks that must be done (Normative Commitment), they can still live the profession because many benefits are gained during the profession (Continuance Commitment). This assumption of linkage is supported by research conducted [25] who found that some of the aspects of quality of work life have a positive relationship with organizational commitment.

\section{Hypothesis}

There is an influence of quality of work life to affective professional commitment There is an influence of quality of work life on continuance professional commitment There is an influence of quality of work life towards normative professional commitment

\section{METHOD}

\section{Research Approach}

The approach used is quantitative with the type of correlational research. Correlational research intends to know the relationship between independent variables with the dependent variables. In this study, the independent variable is the quality of work life and the dependent variable is the professional commitment.

\section{Participants}

Subjects in this study are active teachers in SMP Muhammadiyah, SMK Muhammadiyah, and SMA Muhammadiyah consisting of 40 people. The subjects consists of 17 male teachers and 23 female teachers; the work period ranged from 4 months to 28 years (average 10.2 years). The number of Junior High School teachers is 15 people, the number of SMK teachers is 10 people, and the number of SMA teachers is 15 people.

\section{Data Collection}

The research instrument used is made by Swamy [20] The number of items QWL scale is 42 consisting of 9 aspects, namely: (1) environment, (2) organizational culture and climate, (3) relations (4) training and development, (5) compensation and rewards, (6) facilities, (7) job satisfaction and security, (8) autonomy, and (9) accurate sources. The research instrument used is a questionnaire about the scale of professional commitment and the scale of competence. The scale of professional commitment is an adaptation of the Smith \& Hall [15], the number of items is 29. This scale has 3 dimensions, namely: (1) Affective Professional Commitment (APC), in which individuals want to remain in their profession, identify with professional goals, and want to help the profession to achieve their goals; (2) Continuance Professional Commitment (CPC), in which individuals need to bound to their profession because they have invested; and (3) Normative Professional Commitment (NPC); individuals are required to practice their profession due to meaningful experiences during work or pressure from colleagues and family. Reliability analysis quality of work life scale get value of alpha reliability coefficient equal to 0,96 and profession commitment scale has reliability coefficient equal to 0 , 92. Hence, this scale declared fulfill requirement for subsequent data collection. 


\section{Data Analysis}

This research aims to know the influence of quality of work life to teacher profession commitment. The analysis technique used is simple regression analysis.

\section{RESULTS}

The statistic description showed that the average employment life is 10, 3 years, means quality of work life $=150.72(\mathrm{SD}=45)$, means $\mathrm{APC}=46.8(\mathrm{SD}-5,62)$, means $\mathrm{CPC}=33,82(\mathrm{SD} 6.99)$, mean of $\mathrm{NPC}=34,62$ $(\mathrm{SD}=5,04)$.

The result of product moment analysis found that there was a significant positive correlation between QWL with APC ( $\mathrm{r}=0.062 ; \mathrm{p}=0,000)$, a positive correlation between QWL and NPC ( $r=0,0705 ; \mathrm{p}=0,000)$, and no correlation between QWL with CPC $(r=243$; $p=0.131)$.

The result of regression analysis proved that there was an influence of QWL to APC $(\mathrm{F}=21,577 ; \mathrm{P}=$ $0,000)$ with contribution of $36,2 \%$, no influence of QWL to CPC $(\mathrm{F}=2,378 ; 0,131)$, and there was an influence of QWL to NPS $(\mathrm{F}=42,660 ; \mathrm{P}=0,000)$ contribution equal to $52,9 \%$.

\section{DISCUSSION}

The research found that QWL of teachers influences APC. It means that teachers who have high QWL will show AC which is also high, while teachers who have low QWL then APC will also be low. Similar to these results, high QWL will be followed by high NPC, and low teacher QWL will be followed by low NPC.

Researcher did not find any research related to these two variables. However, research on QWL and organizational commitment already exists. Assuming that the conceptual difference between professional commitment and organizational commitment lies only in the subject of commitment, many studies have shown that quality of work life influences organizational commitment [12][1][10]

Teachers who have assessed the school organization have provided their needs and welfare. They should enjoy the work, be proud of their profession, and fulfill all the tasks assigned to them willingly as an obligation that must be done.

Another analysis found that QWL teachers do not affect CPCs. This may be due to teachers who have already gained what is expected from school, and then they do not have a permanent tendency in their willingness to look at their profession only because of work compensation or pressure.

\section{CONCLUSION}

This study conducted to teachers found that quality of life influences two dimensions of professional commitment: affective commitment and normative commitment. In contrary, quality of work life does not affect continuance commitment.

\section{REFERENCES}

[1] Afşar,ST . 2014. Impact of the Quality of Worklife on Organizational Commitment: A Comparative Study on Academicians Work for State and Foundation Universities in Turkey . International Journal of Social Sciences Vol. III (4)

[2] Chang, Ya-Li \& Wan, chih-Wei. 2012. Professional commitment as an intervening variables in the relation of professional socialization and adaptive performance. Business and Information ( Sapporo, July 3-5)

[3] Emami, M. 2012. Investigating the job satisfaction and professional commitment. Elixir Human Resource Mgmt. 48 (2012) 9652-9655

[4] Hasanati N . 2017. Pengaruh Kompetensi terhadap Komitmen Profesi pada dosen. Jurnal Analitika, Vol. 9 (1) Juni (2017).

[5] Hasanati N . 2015. Pengaruh motivasi berprestasi terhadap kompetensi dan komitmen profesi dan dampaknya pada kinerja dosen Universitas Muhammadiyah Malang. Disertasi. Unpad : Bandung

[6] Hen \& Kao, 2012. Work Values and ServiceOriented Organizational Citizenship Behaviors: The Mediation of Psychological Contract and Professional Commitment: A Case of Students in Taiwan Police College. Social Indicator Research. May 2012, Volume 107, Issue 1, pp 149-169

[7] Li A \& Early SF \& Mahrer NE \& Klaristenfeld \& Gold J. 2014. Group Cohesion and Organizational Commitment: Protective Factors for Nurse Residents' Job Satisfaction, Compassion Fatigue, Compassion Satisfaction, and Burnout. Journal of Professional Nursing, Volume 30, Issue 1, p1100

[8] Lu \& Chang \& Wu . 2007. Relationship between professional commitment, job satisfaction, and work sress in Public Health nurses in Taiwan . Journal of Professional Nursing, Vol 23, No 2 (March-April), 2007: pp 110-116

[9] Lu KY, Lin PL, Wu CM, Hsieh YL, \& Chang YY. 2002. The relationships among turnover intentions, professional commitment, and job satisfaction of hospital nurses. Journal of Professional Nursing. Volume 18, Issue 4,

[10] Normala, Daud . 2010. Investigating the Relationship between Quality of Work Life and Organizational Commitment amongst Employees in Malaysian Firms. International Journal of Business and Management Vol. 5, No. 10; October 2010

[11] Özdem G . 2012. The Relationship between the organizational citizenship behaviours and the organizational and professional commitment of secondary school teacher. Journal of Global Strategic Management, V. 6 ,N. 2. 
[12] Sajjad, NK \& * and Abbasi, B. 2014. Studying the Relationship between Quality of work life and Organizational Commitment. Research Journal of Recent Sciences. Vol. 3(2), 92-99, February (2014)

[13] Scobel, D. N. (1975). Doing away with the factory blues. Harvard Business Review. 53, Nov-Dec., 132-142.

[14] Sirgy, M. J., Efraty, D., Siegel, P. \& Lee, D. J. (2001). A New Measure of Quality of Work Life (QWL) Based on Need Satisfaction and Spillover Theories. Social Indicators Research, 55, 241302.

[15] Smith D \& Hall M (2008) An Empirical Examination of a Three-Component Model of Professional Commitment among Public Accountants. Behavioral Research in Accounting: Spring, Vol. 20, No. 1, pp. 75-92.

[16] Somech, A \& Bogler, R. 2002. Antecedent and Coscequences of Teacher Organizational and Professional Commitment. Educational Administration Quarelly. 38 . http://eaq.sagepub.com.

[17] Sorensen, TJ and McKim2, AJ.2014.Perceived Work-Life Balance Ability, Job Satisfaction, and Professional Commitment among Agriculture Teachers. Journal of Agricultural Education, 55(4), 116-132

[18] Straw, R. J., \& Heckscher, C.C. (1984). QWL: new work relationships in the communication industry. Labor Studies Journal. 8 Winter, 261274

[19] Subejo \&Troena EA \&Thoyib A \& Aisjah A. 2013. The Effect of Organizational Commitment and Organization Identity Strength to Citizenship Behaviour (OCB) Impact On Fire Department and Disaster Employee Performance in Jakarta
Indonesia. IOSR Journal of Business and Management (IOSR-JBM). Volume 10, Issue 3, PP 30-36

[20] Swamy D.R \&Nanjundeswaraswamy \& Rashmi S.2015. Quality of Work Life: Scale Development and Validation. International Journal of Caring Sciences May-August 2015 Volume 8 Issue 2 Page 281.

[21] Tandiontong, M .2013. Pengaruh faktor komitmen profesi akuntan, komitmen organisasi kantor akuntan publik dan kepuasan kerja auditor terhadap implementasi audit independen atas laporan keuangan: Survei terhadap Akuntan yang bekerja sebagai Auditor pada KAP di Indonesia. Jurnal UIlmu Manajemen dan Bisnis . Vol 4, No 1

[22] Wang, X.,Shen,J. 2012. An Investigation in to the Professioal Commitment of Chinesse Project Management Professional. International Journal of Business and Management. , vol.7. no.10

[23] Wu SFV \& Lee MC, Liang SY \& Chuang YH \& Lu YY \& Wu MP. 2012. Self-efficacy, professional commitment, and job satisfaction of diabetic medical care personnel. Contemporary Nurse , 43(1): 38-46.

[24] Yang HH \& Huang FF \& Lai YH, Hsieh CJ \& Liao YS \& Chao WC \& Chen SF. 2010. Perceived Organizational Culture, Professional Commitment, Advice Network and Job Satisfaction of Novice Nurses. WSEAS TRANSACTIONS on COMMUNICATIONS. Issue 9, Volume 9

[25] Yasin T \& Khalid S . 2015. Organizational Cynicism, Work Related Quality of Life and Organizational Commitment in Employees. Pakistan Journal of Commerce and Social Sciences, Vol. 9 (2), 568-582 